\title{
Gender Mainstreaming as a Strategy for Promoting Gender Equality in Lithuania
}

\author{
MEILUTE TALJUNAITE* \\ Institute for Social Research, Vilnius
}

\begin{abstract}
The article deals with the questions of gender policy formation and women's participation in Lithuanian political and civil life. It is based on the results of the EU 5th Framework project 'Enlargement, Gender and Governance: The Civic and Political Participation of Women in the EU Candidate Countries'. Drawing on qualitative data from interviews with women politicians and activists, the article mainly describes gender mainstreaming as implemented through 'transversal' action plans for gender equality. These action plans assign responsibility to different units for the delivery of different objectives. The author points out that 'transversalism' involves no necessary change in policy-making structures or practice, and argues that gender mainstreaming continues to be designated as a distinct or separate policy space in Lithuania. The author also notes that the absence of a stable commitment to gender mainstreaming and the general policy culture of Lithuania are not conducive the evaluation and impact assessment activities in this area.
\end{abstract}

Sociologický časopis/Czech Sociological Review, 2005, Vol. 41, No. 6: 1041-1055

\section{Introduction}

This article deals with the questions of gender policy formation and women's participation in Lithuanian political and civic life. Gender mainstreaming is a long-term strategy designed to promote equality between men and women. It stands for anchoring a gender-sensitive perspective into mainstream planning and decision-making processes. Though gender mainstreaming is not a discrete topic but rather a fundamental principle, its implementation in all policy areas is somewhat controversial. The aim of the article is to observe the formation, implementation and evaluation of gender policy by different social actors and women's NGOs, and it addresses the following main questions:

To what extent has gender equality policy changed with the changes that have occurred in the political and economic infrastructure?

How is gender mainstreaming regarded and understood by key policy actors?

How is gender mainstreaming implemented and what is its progress?

To what extent does gender mainstreaming contribute to good governance?

\footnotetext{
* Direct all correspondence to: Meilute Taljunaite, Saltoniskiu st. 58,Vilnius LT-08105, Lithuania, e-mail: meilutet@yahoo.com
}

(C) Sociologický ústav AV ČR, Praha 2005 
In the national study conducted for the 5th Framework Programme 'Enlargement, Gender and Governance: The Civic and Political Participation and Representation of Women in EU Candidate Countries' (EGG), a review was first made of the literature on the subject and then an analysis was made of gender policy in Lithuania in order to define and specify the concepts of interest in the study in the context of emerging evidence about the current state and progress in the integration of gender equality into public policy at the national level. In the EGG study analytical, conceptual and methodological frameworks were elaborated for the country research, which was based primarily on interviews with professionals and experts involved in women's issues and with a range of different stakeholders in the policy processes studied, and on analyses of key documents, particularly legislative texts, surveys and studies on the context of policy formulation and design, policy guidelines, policy reviews, and evaluation reports. The expert interviews were collected and simultaneously analysed at the beginning of 2005. The interviews with policy makers and participants cover the following four categories of relevant actors:

- officials - individuals responsible at present for gender equality (policy staff in parliament, officials in government and in government departments, staff from the Office of the Ombudsman) (5 interviews);

- activists - prominent women leaders from the past or present in democratisation movements at the local level (municipalities) (5 interviews);

- women's NGOs - feminist NGOs focusing on women's rights (9 interviews);

- gender/feminist researchers - those working in the academic or other intellectual spheres (10 interviews).

Gender mainstreaming originated with the realisation that women and men, owing to their social and cultural gender, encounter different conditions and opportunities in life, have different interests and needs, and are differently affected by societal processes. Gender mainstreaming considers women and men and their different positions in society and aims at changing the underlying conditions and structures that generate inequality. While there has been much innovation in developing gender mainstreaming, progress has been uneven within each country. In Lithuania gender mainstreaming efforts are present, but they are highly fragmented, confined either to a particular policy domain or to a specific programme within a domain, and disconnected from general governmental policy on gender. Lithuania is a case apart by virtue of its particular history and by the speed of its transition.

There are three components to gender mainstreaming policy that are applied in Lithuania to a greater or lesser degree:

1. The setting up of dedicated gender mainstreaming units staffed by people with the skills to provide technical support, as necessary, to various parts of the administration;

2. The introduction of policy evaluation and monitoring mechanisms, particularly gender impact assessment methods and regular reporting mechanisms (for example, 'Equal Opportunities for Women and Men' - a sub-programme of the Network Women's Programme and the Open Society Foundation Romania run between March 2001 and June 2002 (http://www.eonet.ro); 
3. Implementing changes in the way that policy is made, in particular, increasing social dialogue with the voluntary sector through the institutionalisation of consultation practices, the creation or consolidation of advisory bodies representing women's groups, and equipping women's representatives with the necessary skills to participate in policy making.

Lithuania follows a very similar strategy of gender mainstreaming as that in other EU countries. Recent government documents explicitly refer to gender mainstreaming either as an objective or as a principle governing gender equality policy. However, despite these formal commitments to gender mainstreaming, and except for a few initiatives, there is very little evidence that this approach is actually being implemented. Both the understanding of the gender equality issue and the objectives of policy reveal a significant degree of fragmentation in different government departments (and policy domains) within the country. There is also evidence that 'gender mainstreaming' is exploited to serve diverse political needs: politicians and government officials conveniently use the term 'gender mainstreaming' to refer to a move from a focus on women to a more neutral focus on gender (which is simply understood as referring to both women and men) as the primary focus of equality policy. The term 'gender mainstreaming' mainly functions as a new name for 'old' policy practices, such as positive action measures, transversal national plans involving different departments of the administration, and even equal treatment legislation. For instance, although it is true that the EU countries tend to use a similar line of rhetoric regarding the need to attend to the structural and cultural roots of gender inequalities, in Lithuania, as in many other countries, there is a significant gap between rhetoric and practice.

Equal treatment legislation has also undergone important developments. In Lithuania such legislation has been reformed to broaden both the concept of discrimination, to include indirect discrimination, and the sphere of its application, to include, for example, public services and facilities, as well as education and the workplace. Analysis conducted as part of the country study for the EGG on the laws of the Republic of Lithuania with regard to aspects of the principle of gender equality showed that the country's main laws do not in principle conflict with the equality principle or the legal instruments of the European Union and other international organisations.

Equal opportunities for women and men are established in many of Lithuania's laws: the Act on Elections, the Referendum Act, the Employment Contracts Act, the Civil Service Act, the Work Safety Act, and the Act on Support for the Unemployed, and other laws and codes. The National Programme for Equal Opportunities for Women and Men (2003-2004) can be viewed as the second level of the implementation of the principle of gender mainstreaming in the country. Responsibility for the co-ordination, delivery and implementation of the Mainstreaming Strategy lies with the Equality Commission within the Lithuanian government. However, to ensure that society really adheres to the principle of equal opportunities for women and men, the positive attitude of legislators towards this issue and a sufficiently well developed mechanism in state institutions to address related issues are 
alone not sufficient. That is why at the heart of the equality mainstreaming approach in Lithuania there is the very strong influence of the third sector, NGOs, and academics. Gender mainstreaming initiatives in Lithuania tend to emerge as a result of a great deal of effort and perseverance from individual women in key positions of power ${ }^{1}$ (e.g. ministers, senior civil servants, MEPs), or even women's organisations, rather than decisions, at a high governmental level, to pursue a new gender equality policy approach.

\section{Progress in gender mainstreaming}

Lithuania has made a formal commitment to implement a gender mainstreaming approach to gender equality. However, there is evidence of a significant level of variation, first, in the extent to which this commitment is being or has been fulfilled, and second, in the methods or strategies that are being utilised to realise this commitment. The term 'gender mainstreaming' lacks a clear and concrete meaning, and therefore, it tends to operate as a catch-all phrase, used to refer to a variety of approaches and activities.

There is a general trend in Lithuania to spread responsibility for gender among units or departments. This 'decentralisation' is achieved through: 1) a revision of equal treatment legislation in order to involve all public bodies in anti-discrimination policy; 2) the creation of 'transversal' action plans on gender equality; and, partly, 3) the systematic use of gender analysis tools in the design and implementation of all other policies.

The evaluation of gender mainstreaming in Lithuania indicates that it is 'transversional' in character. According to Mary Daly's description [2004], transversalism, albeit in different forms, is a quite widely used response or strategy, especially in the form of action plans that assign responsibility to different units for the delivery of different objectives. Daly underlines the need to scrutinise transversalism carefully, as while it appears to be synonymous with gender mainstreaming, it is a somewhat different phenomenon. First, it involves no necessary changes in policy-making

\footnotetext{
${ }^{1}$ Just a few examples: 1) The very day after the Lithuanian Parliament declared the country's independence restored on 11 March 11 1990, Kazimiera Prunskiene, a professor in economics from the University of Vilnius and a well-known leader of Sajüdis, became the Prime Minister of Lithuania. At that time, Lithuania was the only transition country in all of Eastern and Central Europe where a woman headed the ministerial cabinet. Nonetheless the phenomena of Prunskiene in 1990-1992 was more a symbolic challenge than an actual innovation in favour of women' political involvement. She was the only woman among the seventeen cabinet members. She was the first (and the only) woman to participate in the presidential elections in 2003 in Lithuania; 2) In November 1999, Ugne Karvelis, a female Permanent Representative of the Republic of Lithuania to UNESCO, was elected vice chair of the UNESCO Executive Board for a two-year term. 3) In January 2001 Gintė Damušytė was appointed to head the Lithuanian mission at NATO in Brussels. No woman had ever before (since 1949, when the organisation was created) occupied the position of ambassador to this organisation.
} 
structures or practices, and second, gender equality continues to be designated as a distinct or separate policy space (even though each department or unit under transversalism may eventually be assigned gender equality objectives). Transversalism does not integrate gender into the core of policy, but tends rather to add it on top, as an additional objective or consideration. Another trend in Lithuania is to address gender mainstreaming by means of selectively adopting some of its components, and especially some of its tools or techniques, without the overall framework. In terms of which components or methods are favoured, the view of gender mainstreaming is more or less as synonymous with a gender analysis of policies.

\section{Interpreting gender mainstreaming: how the issue is understood and addressed}

Gender equality surfaced relatively late in the agenda of the negotiations on joining the EU. Much greater priority was placed on social and economic reforms based on neo-liberal principles that lacked a gender perspective. On the basis of documentary analysis and events mentioned by the respondents as crucial for the process of establishing gender mainstreaming in Lithuania the chronology of changes in concepts on women's issues in Lithuania is described in the table below:

Table 1: A chronology of concepts on women's issues

\begin{tabular}{ll}
\hline Gender inequality & $1989-1990$ \\
Feminism & $(1991)$ \\
Women's issues (Beijing conference influence) & $1995-1996$ \\
Gender equality & 2000 \\
Gender mainstreaming (National Programme) & $2003-2004$ \\
Equal opportunities (changes to the status of Ombudsman and to the law) & 2005 \\
\hline
\end{tabular}

\section{Gender inequality}

Part of the appeal in the concept of equality is that it contains a big vision, a view of society and of the relations between women and men that are embedded within it. However, given how general the meaning of gender equality is, and that it is a concept that is open to multiple interpretations, some respondents prefer to focus mainly on gender inequality. Gender equality thus serves the purpose of a guiding principle or ideal, whereas gender inequality draws attention to the concrete, 'real world' issue.

It is possible to notice a consistent pattern in gender inequality, which enables the discovery of some problematic 'points' of gender relations or, figuratively speaking, are indicative of some gender 'conflict'. Both men and women believe that representatives of the opposite gender live a better and easier life. The percentage of 
men who think that the law is more favourable to women, that the state pays more attention to women, and so on, is greater than the percentage of women who do so, and, conversely, the percentage of women who claim that men are more privileged in various areas is greater than the number of men who hold this opinion.

\title{
Feminism
}

During the development of democratic movements in Lithuania, women's movements were also created. Therefore, in the interviews with experts and professionals on women's issues, they were asked whether it is possible for a feminist movement in Lithuania to really develop. Despite Lithuania's transition and independence and the current existence of a generally liberalised society, there are still somewhat strong features testifying to the persistence of totalitarian attitudes. It could be assumed that the prior experience of gender policy in Lithuania means that the possibility of any active feminist movement must be put off for a long time.

At present, the patriarchal attitudes towards family problems are a good background for a political career, because it is considered as opposition to the totalitarian 'Soviet' past. So, if somebody wants to be accepted in this society he or she cannot speak as pro-feminist. (Researcher, and a figure involved in gender mainstreaming)

If this is the case it must be expected that in the immediate future feminist ideas in Lithuania will be restricted to the confines of Women's Studies programmes, while certain types of pro-family institutions will be active. While at first glance there appears to be a strong inclination towards feminism at secondary schools and universities, this is not the case, with the exception of a few Women's Studies Centres (NGOs). It is also important to note that women's movements in post-socialist countries in general rarely describe themselves as 'feminist':

\begin{abstract}
...Above all because feminism is associated more with a hatred of men and with lesbianism, than with the social transformation of society in connection with women's interests. That is why feminism still has a strictly negative undertone and very seldom does even an independent woman dare to officially identify herself as a feminist. (NGO activist)
\end{abstract}

First, feminism is policy, and second, it is a scientific substantiation of this policy. My work is related to women's issues, but what is declared by radical feminism is unacceptable to me. My profession is primary. I am not active, that is why I could not consider myself a feminist, surely not a radical feminist. At the same time, I can consider myself a feminist because I am worried about equality between men and women, which does not exist in society. (Researcher)

Recent developments to explain the persistence of gender inequality across societies centre on gendered welfare states. As feminists have shown, the state is al- 
ways gendered, especially in the case of specific types of welfare policies, such as taxes and benefits, or care institutions. Modern feminism highlights the 'stereotype' as closely linked to gender and gender identification, both in the cultural and the social- historical environment. A stereotype is a simplified, easily recognised social meaning: 'It is something fixed, stable and usually has a negative overtone?' (Researcher)

\section{Gender equality}

The equal treatment (equal rights) perspective was the dominant perspective in what has come to be called 'first wave feminism', a period in which feminist theory and action was largely informed by liberalist principles and theory. In this period the feminist struggle was for the formal equality of women within the existing system of rules and laws. Thus the equal treatment perspective promotes action aimed at guaranteeing women the same rights and opportunities as men in the public sphere. This assessment is part of a wider feminist critique of modern liberal political thought and its application to the issues of gender equality. In the face of these feminist and other critiques of liberal notions of equality, the concept of difference has emerged as one of the central motifs in feminist analysis today. This new perspective focuses on the recognition, valorisation and celebration of gender difference. Such thinking has found its way into policy, where one can see a clear shift of emphasis from equality to difference. However, this new emphasis on gender difference is itself highly controversial for a number of reasons. To summarise, the gender perspective, focusing as it does on difference, represents a major development in the thinking on gender equality. It offers a profound critique not just of policy approaches but also of the conceptual and philosophical foundations of theoretical thinking about equality.

Gender mainstreaming is seen as offering an improvement, building on the strengths, and also the known weaknesses, of the two existing models - the advancement of women, and gender mainstreaming. This approach moves away from focusing solely on women and has the potential to regard men as a disadvantaged group (e.g. in relation to their rights as fathers or family members). In this perspective society itself is at fault for creating, through social practices and structures, fixed and gendered role models and expectations for women and men. The Ombudsman in Lithuania changed its name from the Ombudsman for 'Equal Opportunities for Men and Women' to the 'Equal Opportunities' at the beginning of 2005. Activists at women's NGO were against this change, which they interpreted as a loss of what they had achieved. Gender issues are sometimes regarded as only transitional issues.

The custom of linking gender policy and family policy questions is still very much alive and visible in Lithuania. Gender mainstreaming ought to contribute to the democratisation and modernisation of various structures in the country. The 
link between family and work life is the main factor that is governed by gender stereotypes, which is an interesting subject for research. What can be agreed is that changes should be promoted in social and organisational cultures, and likewise to foster media awareness to change the predominant societal view of gender stereotypes.

The interviews conducted in the research revealed quite interesting interpretations of the specific 'Lithuanian' policy approach to gender mainstreaming, but the prevailing approach to gender equality is to look at it through 'family glasses'. But at the same time the spread of the traditional family model is not realistic under current economic circumstances (although women's unemployment is evidently favourable to the development of the traditional type of family). Although the gender mainstreaming approach is considered an important foundation stone for the future, at this point direct and intensified support that targets women is still considered essential. The efficient implementation of gender mainstreaming would require, beyond a general recognition of and commitment to the advancement of women, that all staff in the fields of education, research, employment, and human rights be specially trained in issues relating to the advancement of women. The general trend in Lithuanian policy nowadays is evaluated more negatively than positively by women - the actors in gender mainstreaming - who were very active at the beginning of gender mainstreaming in Lithuania, and as a turn away from positive action to achieve women's equality and instead towards general questions of equality on various bases. On the other hand, young representatives of NGOs evaluated the general trend and many activities and programmes in very positive terms. Some women in the interviews pointed to disturbing signs that the government, which in order to be able to join the EU introduced the minimum equality-related mechanisms required for accession, is now taking indirect steps to de-activate or dilute such measures. They point to the fact that the institutional mechanisms of gender equality (e.g. the Ombudsman for Equal Opportunities for Men and Women) have recently been transferred to the Equal Opportunities Ombudsman Office, which in addition to gender equality also deals with a host of other issues, including discrimination against minorities, the disabled, etc.

\section{Who implements gender mainstreaming and how}

Since the strategy for gender equality is based on the broad principles of partnership, a number of different stakeholders participate in its implementation. The agency that leads the way in the promotion and implementation of gender equality policy is the Equality Commission in the Lithuanian government, which falls under the Ministry of Social Security and Labour. However, the National Programme for Equal Opportunities for Women and Men is implemented by public administration through inter-departmental agreements, with each ministerial signatory responsible for their own particular component in the National Programme, and with some of the cited priorities explicitly referring to the involvement of non-state agencies 
(without mentioning their specialisation; no mention is made of trade unions). Between 1994 and 2005, the position of State Counsellor (advisor) on Women's Issues existed. During that period, the State Counsellor on Foreign Relations and Relations with NGOs was responsible for these issues. In the Ministry of Social Security and Labour and in the Department of Statistics positions were created to take up the responsibility for gender issues. The use of gender-disaggregated statistics was evaluated very favourably and as very useful by various actors in gender mainstreaming. MPs and NGOs mentioned that they used statistics of this type and are grateful to be able to obtain them from the Department of Statistics almost whenever necessary. An inter-ministerial commission was formed by the Ministry of Social Security and Labour to monitor the implementation of the Action Plan for the Advancement of Women. But the main barrier to gender mainstreaming in the view of one governmental official is that all ten districts, that is, the entire country, are outside her competence for implementing the National Action Plan:

I cannot communicate directly with sixty municipalities, and there is no person responsible for equality policy implementation at administrations in the districts. (Government Official)

Apart from this, the implementation of the strategy is carried out in connection with other programmes and projects carried out by both governmental and non-governmental agencies. During the first two years of its implementation the strategy is to be monitored by an independent implementation group, which will oversee the strategy's progress and impact.

\section{The main actors in the policy process}

Gender mainstreaming is mandatory under the Treaty of Amsterdam and as such it is reflected in all the policies and guidelines of the European Union. In Lithuania it was the Ministry of Social Security and Labour that resolved to have gender mainstreaming implemented at all levels. Under the regulation governing the co-ordination of activities of all the ministries, this resolution also applies to the Ministry of Education and Science.

The Government Programme for 2000 to 2004 placed a high priority on reducing the authority of central ministries, consolidating county administration and increasing the authority and responsibility of municipalities. A few of the gender mainstreaming actors also described this tendency in gender policy formation: ministries $\rightarrow$ municipalities (e.g. education departments) $\rightarrow$ schools (universities) as the direction of decentralisation. The most positive comments were received on the commissioning of gender research. Respondents from various groups (officials, researchers, NGOs) emphasised the importance of gender research and its 'pioneering' role in the formation and implementation of gender mainstreaming in Lithuania. The Government Programme was the only programme mentioned by respon- 
dents as the main gender impact assessment tool. One respondent, the head of a woman's NGO, noted: 'The legal background exists, but without practice'.

\section{Equal Opportunities Ombudsman}

In compliance with the Act on Equal Opportunities, the office of an Equal Opportunities Ombudsman has been set up. The Equal Opportunities Ombudsman investigates complaints relating to cases of discrimination and sexual harassment. The Ombudsman reports on the implementation of laws and submits recommendations to the government and administrative institutions on the revision of legal acts and priorities in the policy for the implementation of equal rights. It is a national initiative, and relations with other organisations outside the country are not its responsibility. The officials from this department emphasised in the interviews that gender mainstreaming is a kind of social policy, because a whole system for gender policy implementation has been established. They cited the Swedish model as the best example of gender mainstreaming and proposed the decentralisation of the system. In their opinion a feature specific to Lithuania is that only women's NGO's are really active in gender mainstreaming.

\section{Women's NGO initiatives}

The number of NGOs dealing with women's issues has recently been increasing. These NGOs are gaining momentum and becoming more and more important in society. In the last couple of years the establishment of local NGOs has been more prevalent. The number of women's organisations has greatly increased and there are currently 63 women's organisations active in Lithuania. They have also become more powerful and more active, and they played an important role in drafting the Act on Equal Opportunities for Men and Women. These organisations can be distinguished into two groups: women's groups within political parties, and non-governmental women's organisations. There are women's groups in the five biggest political parties of Lithuania: the Lithuanian Centre Union's Women's Section, the Lithuanian Democratic Women's Group (within the Lithuanian Democratic Labour Party), the Lithuanian Social Democratic Women's Union, the Union of Women Conservatives (Homeland Union - Lithuanian Conservatives), and the Women's Section of the Lithuanian Christian Democratic Party. In the third sector many of the women's NGOs are established as interest groups. Their membership varies greatly; some have as few as nine members and others as many as 10000 . According to the Directory of Women's Organisations of Lithuania (a summary publication on women's organisations in Lithuania), twenty of these organisations declared the sphere of policy and decision making as their priority activity in 2000 [Directory of Women's Organisations in Lithuania 2000]. The training of officials in gender mainstreaming concepts and methods was a more popular idea among representatives of 
NGOs than among relevant officials at the ministries. Public women's organisations are also very diverse. Some of them act at the national level (17 such organisations), others at the regional or municipal level, or within other organisations (e.g. women's studies centres at universities). Some of these organisations have set a very clear goal of equal rights and opportunities, others direct their activities towards assisting women or uniting women on the basis of profession, interests, religion, nationality, etc. Ten international women's organisations have increased their activities (e.g. Sorooptimists, Zonta, etc.).

One crucial event that had an impact on NGO initiatives was the establishment of the Lithuanian Women's Party (with Kazimiera Prunskiene as party leader) in February 1995. The primary concern of the party was the status of women, and it invited all women to unite and participate in solving the urgent problems society is faced with. Membership was however open to both sexes. The political programme of the Women's Party included sub-programmes on the status of women, the legal system, politics and ethnic minorities, rural issues, health and environment, foreign and international policies. Soon after the parliamentary elections in 2000 (in which the party did not succeed as it failed to obtain the necessary $5 \%$ of the vote to be represented in Parliament) the Women's Party changed its name to the New Democracy Party. During the elections in 2004 a new coalition was formed between the Union of Farmers Party and the New Democracy Party. Gender equality issues are mentioned in the programmes of these parties.

The Lithuanian National Women's Forum, Parliament's advisory board, was only re-established at the end of April 2003 (there were a few attempts to create this board just after the parliamentary elections in 1990). Today it plays quite an important role in coordinating the joint participation of NGOs, Parliament and government officials. The Vision for the Development of an Egalitarian Society in Lithuania by 2014 (a non-governmental document, prepared by volunteers: Ina Dagyte, Esmeralda Kuliešytė, Giedrẻ Purvaneckienè, Ramunè Trakymienè, and Vilija Vasiliauskienè) was adopted in February 2004. The strategy for co-operation between NGOs and governmental structures was prepared by the same group of volunteers and is currently being implemented. The 'Vision' document also calls for the establishment of a Ministry of Equal Opportunities for Women and Men, and mentions distinguishing between the activity of an Ombudsman for Women and Men and the Ombudsman for Equal Opportunities (the latter has replaced the former) in employment: 'One of the main spheres of its activities is the improvement of women's status in the society and receiving gender statistics from the employers. All employers' accounts for statistical indicators about women progress in their annual reports.' (Vision for the Development... 2004)

The Women's Issues Information Centre (an NGO that was supported by the UNDP at its beginning) ranks among the strongest women's organisations. The centre acts in close collaboration with the Prime Minister's Office. It also issues publications on women's issues and distributes them throughout the country. Their aim is to help women understand their rights and become knowledgeable about exer- 
cising their rights in real life. As a catalyst for the advancement of women's organisations the centre directs the activities of women's organisations towards finding solutions to critical problems, and it co-ordinates joint action and events. Apart from that the centre is involved in publishing the monthly bilingual Lithuanian-English magazine 'Woman's World', which is distributed free of charge, and it also publishes other publications on gender equality issues. The centre collects and classifies gender-related statistical data and the results of social studies, and it initiates projects and studies on women's issues, along with organising conferences, seminars, workshops and training courses aimed at raising awareness and cultivating understanding of gender equality, performing the role of an educational institution by disseminating information on gender equality issues. The enormous participation of the Women's Issues Information Centre in various projects was cited by the actors in gender mainstreaming as the main source of civil activities, and its involvement in different projects was stressed as playing a huge role and as the source of the subsequent organisation of numerous projects. Respondents from other more or less institutionalised units like the Women's Information Centre noted that they do not function as a formal coalition but rather participate in these activities through projects.

Funds were the main driving force behind the development and progress of women's studies in Lithuania:

At the beginning of the Women's [studies] Programme, the programme co-ordinator used the directory of women's organisations in Lithuania [published in 1998] and called on them personally to inform them about Open Society Fund-Lithuania initiatives and the possibilities for participating in one event or another. (NGO activist)

Nearly all the actors in gender mainstreaming ranked the influence of various donors and funds in the same order, and these donors and funds are indicated as the main social partners that have supported and encouraged various projects in Lithuania on women's issues and programmes: UNDP; the PHARE Programme; the Open Society Fund - Lithuania, the Nordic Council, and the European Community. NGO representatives gave the same positive evaluations of international co-operation and in the same areas: financial support; the opportunity to participate in conferences, etc. (mobility); the ability to receive important information; new experiences; networking. They also mentioned several barriers: the huge fees connected with participating in international organisations (for example, about 700 euros for the European Women's Lobby); the sometimes huge fees for participation in seminars organised by foreign institutions in Lithuania (this problem was cited by entrepreneurs involved in women's issues); not all information that passes through government institutions reaches the NGOs, especially in the periphery, which is why the NGOs prefer to establish their own direct networks with international partners; for those interested in gender issues in Lithuania it continues to be difficult to co-ordinate activities and to work in 'teams'. Only one fact was mentioned as an ex- 
ample of positive action to improve the representation of women in decision-making: the women's NGOs campaign during the municipal elections in 2002-2003 (the campaign was to get women on the ballot), when every third candidate in the lists was a woman (but few parties applied this strategy). Today the same initiative is targeting the first elections to the European Parliament (as part of the activities of the European Women's Lobby). The pre-election campaign is called 'Women Voting for Women' and is being organised by NGOs (through a website and printed letters), and the NGO's are sending letters to the heads of all parties calling on them to include more women on their party candidate lists and it seems to have some effect. The actors in gender mainstreaming only commented negatively on the idea of setting gender-specific target quotas in different spheres.

During the interviews the respondents were asked if they have put in place any of the following methods or procedures: a gender mainstreaming unit; a gender analysis of budgets; gender impact assessment tools; the commissioning of gender research; use of gender disaggregated statistics; the training of officials in gender mainstreaming concept and methods; action to improve the representation of women in decision-making; setting gender-specific targets/outcomes, and others. What are the most important elements of each one? All the actors in gender mainstreaming were able to provide information about gender mainstreaming, but its impact varied significantly. This shows that they are only in the process of formation. The gender mainstreaming unit and the gender analysis of budgets were selected as examples of very new issues for the respondents' comments. Most respondents commented on the gender mainstreaming unit by simply stating that they did not know of it, and only a few of them were able to answer that it is something that exists at only the NGO level. Negative responses also prevailed in response to the question on the gender analysis of budgets, and some of the gender mainstreaming actors agreed that there is a certain lack of information from the government on gender mainstreaming, usually only information that is general and aimed at the public.

\section{Collaboration between actors (inter- and intra-institutional)}

In the Lithuanian national study for the EGG survey the gender mainstreaming actors were asked about the relationship between NGOs and women-officials. Women's NGOs and government institutions co-operate with members of the Women's Parliamentary Group and the Equal Opportunities Ombudsman's Office. They co-ordinate activities between NGOs and other bodies, for example, police institutions in the effort to combat trafficking in women and children. Both NGOs and officials stated in the interviews that these ties are quite close, and they evaluated it as a very positive relationship that exists primarily in the form of joint (personal) meetings, written correspondence (especially during the debates prior to the introduction of a new law), training, round table meetings, and public events (especially before new elections). 
The women in the survey expressed the hope that EU enlargement leads to greater co-operation and interaction with women activists in other parts of Europe. They more often expressed the wish that only very common decisions ('connected more to the economy than the decision-making') be made at the EU level. They seek more space to address their own specific needs (at the national level and at all other levels within the state). Some believe that political action aimed at achieving gender equality could be reinforced through joint initiatives and networks. Other women appear to be more positive about co-operation with the European Women's Lobby as a means of opening up opportunities to identify and work more effectively towards common goals. They also see such collaboration as a way of enhancing the possibilities for improving their level of professionalism and strengthening their working methods and strategies.

\section{Conclusion}

Lithuania warrants attention as a country where the EU influence on gender equality policy is being brought to bear mainly by women's groups which, as the country's key actors in promoting gender equality, have played an important role in lobbying an unsympathetic government to make progress in implementing EU requirements relating to gender, including gender mainstreaming. In Lithuania there is an evident trend of spreading responsibility for gender across units or departments, which could be read as a move away from the centralisation of responsibility for gender, and this is occurring through the creation of 'transversal' action plans for gender equality: action plans assign responsibility to different units for the delivery of different objectives. This 'transversalism' involves no necessary change in policy-making structures or practices, and gender mainstreaming continues to be designated as a distinct or separate policy space. This is not desirable from the point of view of the actors in gender mainstreaming. The lack of stability in the commitment to gender equality and the country's policy culture is not conducive to practices such as evaluation and impact assessment. The results suggest that progress in implementing gender mainstreaming is slow and somewhat patchy.

Equal treatment legislation has made important progress, but not enough. The actors involved in gender equality policy in Lithuania acknowledge the positive effect of the accession negotiations, but they also note that this issue surfaced late in the agenda and that greater priority was placed on social and economic reforms. In all recent governmental documents explicit reference is made to gender mainstreaming either as an objective or as a principle governing gender equality policy. The Act on Equal Opportunities for Women and Men (1998), which was renamed the Act on Equal Opportunities (passed in 2004 and in effect as of 1 January 2005), can be seen a positive step for the implementation of the principle of non-discrimination, set out in the new EU Constitution. But some fear that in practice it could signify a return to the stage of gender inequality that existed up until 1995. The list of spheres that the Act covers should therefore be elaborated and extended to include the equal development of careers for women and men. 
MeILUte TAljunaite is a professor and deputy director for Research and Development at Vilnius Law and Business College, and a senior researcher at the Institute for Social Research. Her main fields of research are European citizenship, European social integration, social stratification, and gender policy. Her most recent publications include a book in Lithuanian on Citizenship and European Social Integration (2005) and 'Social Stratification under European Integration in the Baltic States', published in Baltic States: Looking at Small Societies on Europe's Margin (edited by C. Girdano et al).

\section{References}

A Directory of Women's Organisations in Lithuania. 2000. Vilnius: Moteru informacinis centras.

Daly M. 2004. "EQUAPOL: The Progress of Gender Equality in the Study Countries A Comparative Analysis". A paper presented at the EU Conference "Gender Equality Policy in Europe: Making Progress in Difficult Times", 25-26 November 2004, Athens, Greece.

First Periodic Report on the Implementation of the Provisions of the Convention of the United Nations On the Elimination of all Forms of Discrimination against Women in Lithuania. (no date) Vilnius: Ministry of Social Security and Labour. http://www.socmin.lt

I. Dagytė, E. Kuliešytė, G. Purvaneckienė, R. Trakymienè and V. Vasiliauskienè. 2004. A Vision of the Development of Egalitarian Society in Lithuania to 2014. (in Lithuanian). Vilnius: Office of the Equal Opportunities Ombudsman.

Purvaneckas A. and G. Purvaneckiene. 2001. Moteris Lietuvos visuomeneje. (Women in Lithuanian Society: A Comparative Analysis of Research Data) Vilnius: Gervele.

Women and Men in the Baltic Countries. 2002. Vilnius: Lithuanian Statistical Department, 2002. 